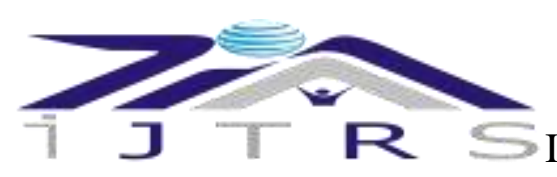

International Journal of Technical Research \& Science

\title{
PERCEIVED PSYCHOLOGICAL STRESS AND BURN OUT AMONG POLICE CONSTABLES OF PUNJAB, PAKISTAN
}

\author{
Maham Rasheed, Naeema Sarfraz, Raheel Ahmed \\ E-Mail Id: Mahamrasheedgcu@ gmail.com \\ Clinical Psychology Department, Government College University (GCU), Lahore Pakistan
}

Abstract-The aim of the study was to explore the relationship between perceived psychological stresses, burn out (exhaustion, disengagement) among police constables (16-55 years). Sample of the police constables was taken from 5 different cities (Sheikhupura, Lahore, Narowal, Kasur and Farooqabad) of police departments. Perceived Psychological stress developed by Sheldon. Olden Burg Inventory developed by Baller and Demographic questionnaire was used for the assessment in police constables. The results indicated that there is a significant correlation between income, burn out and psychological distress. The major contribution of the results is that although the police constables performed the same duty and having the same responsibilities but the level of burn out, perceived psychological stress differs in five cities according to their occupational stress and demand of their jobs. As in the Lahore city there are more security needed and having political addresses from other cities.

Keywords: Stress, Burn out, exhaustion, disengagement, performance, Police constables

\section{INTRODUCTION}

Pakistan has been struggling in battling against terrorism for many years, it has affected people in almost all the provinces of Pakistan (Hassan, 2009). According to Abbas (2009) report, from 2002 till 2005, the total cases of suicidal attacks In Pakistan (Punjab) were fifteen in number, whereas in the duration of four years (i.e., the 2006-2009 period), the number increased to about two hundreds. In such conditions, the role of security forces has become apparent and essential.

The demand for the police officers and these terrorist's attacks have also brought some challenges regarding available resources for police officers. Thus resulting in stress and burnout among police constables. The available resources were not sufficient to deal with the stress level of the police constables. (Siaaiqa, 2009).The rapidly changing environment of social life and increased responsibilities of Punjab police work have increased the level of stress among police officials (Hassan, 2010).

In Pakistan "Policing" is widely considered as a tough and demanding job to give security to others while became the victim of danger at every point (Anderson et al, 2002). Police department performs various duties in which they predict many types of danger such as "crime scenarios, engaging in high - speed targets, controlled the unpredictable situations, handling and resolving the domestic disputes and affairs which makes the high alert psychological stress situations in their daily lives (Finn \&Roberg, 2005).

In Pakistan, the changing environment such as terrorism, unpredictable political issues are the major issues in which it is considered from the police department to provide first line protection and security to society and public. The police-constables encountered the tough duty hours in which they might having major risks without any warning and phone calls. In the police department there is no off day and it is considered compulsory to be available $24 / 7$ either for administrative work or to perform duty, make police job as a highly stressful job. In these circumstances it is necessary to assess and measure the level of psychological stress of such police constables and give awareness to the public about their duties and works so that the labialization of police reduces and might their work acknowledged by government.

\section{METHODOLOGY}

The present study was conducted to find the relationship between perceived psychological stress and burn out among police constables of Punjab, Pakistan.. Co-relational Research design was used to study perceived Psychological Stress and Burn out among police constables. The data was collected by purposive sampling technique. The Sample of 250 police constables with the age range of above 20 years was included in the study. The data was collected from the five cities of the Punjab, province of Pakistan. The Participants $(\mathrm{N}=50)$ were taken from District jail of Sheikhupura, $(\mathrm{N}=50)$ were taken from the District jail of Lahore, $(\mathrm{N}=50)$ were taken from the District jail of Kasur, $(\mathrm{N}=50)$ taken from the District jail of farooqabad by using the Perceived Psychological Stress Scale (PPSS), and Burn out Inventory (BOI) with a Demographic Questionnaire.

\section{RESULTS}

The frequency and percentage indicated that the majority of the participants were Muslims, educated and belong to middle class family. 
ISSN No.: 2454- 2024 (online)

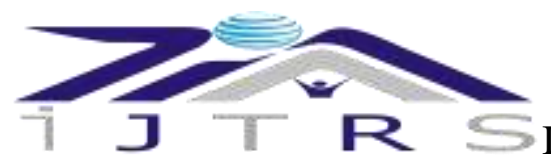

Table-3.1 Demographic Characteristics of the Sample

\begin{tabular}{|c|c|c|c|}
\hline & Demographics & $\mathbf{f}$ & \% \\
\hline Gender & Male & 250 & 100.0 \\
\hline Age & & & 70.4 \\
\hline & Young & 176 & 29.6 \\
\hline Education & Middle & 74 & 1.2 \\
\hline & Illiterate & 140 & 56.0 \\
\hline Family System & Matriculation & 107 & 42.8 \\
\hline & Graduate & 139 & 55.6 \\
\hline Martial Status & Nuclear & 111 & 44.4 \\
\hline & Joint & 147 & 58.8 \\
\hline & Single & 103 & 41.2 \\
\hline
\end{tabular}

Note: $\mathrm{f}=$ frequency, $\%=$ percentage

Table 3.1 shows the demographic information of the sample which includes gender, education, family system, age and marital status. The sample consists of 250 police constables from five different cities of Punjab, province. Qualification categories of participants consists of nil qualification $(f=3, \%=1.2)$, matric $(\mathrm{f}=140, \%$ $=56.0)$ and graduate $(\mathrm{f}=107, \%=42.8)$. Family system of participants consists of nuclear $(\mathrm{f}=139, \%=55.6)$ and joint $(\mathrm{f}=111, \%=44.4)$. The marital status shows that most police constables are single $(\mathrm{f}=147, \%=58.8)$ and less participants are married $(\mathrm{f}=103, \%=41.2)$. The age categories of participants divided into two subgroups, young participants ( $\mathrm{f}=176, \%=70.4)$ and middle age participants $(\mathrm{f}=74, \%=29.6$ ).

Table-3.2 Alpha Reliability Coefficients of Perceived Psychological Stress, Burn out (Exhaustion \& Disengagement) $(\mathrm{N}=\mathbf{2 5 0})$

\begin{tabular}{|c|c|c|}
\hline Scales & k & a \\
\hline PPSS & $(\mathbf{N = 2 5 0}$ & .63 \\
\hline Bum out & 16 & .80 \\
\hline Exhaustion & 08 & .78 \\
\hline Disengagement & 08 & .64 \\
\hline
\end{tabular}

Note: $\mathrm{a}=$ reliability coefficient, $\mathrm{k}=$ no of items

Table 3.2 showed the reliability coefficients of psychological stress, Burn out and its subscales. The results showed that all scales and subscales have good internal consistency. Although the Burn out scale (OBI) showed higher internal reliability $(\mathrm{k}=16, \mathrm{a}=80)$, its subscales also showed higher internal reliability such as burn out exhaustion $(\mathrm{k}=08, \mathrm{a}=.78)$ and burn out disengagement $(\mathrm{k}=08, \mathrm{a}=.64)$.

Table-3.3 Correlation matrix of Perceived psychological Stress, Burn out (Exhaustion \& Disengagement) in Police Constables $(\mathbf{N}=\mathbf{2 5 0})$

\begin{tabular}{|c|c|c|c|}
\hline Variables & 1 & 2 & 3 \\
\hline PPSS & - & 0.7 & 0.7 \\
\hline Exhaustion & - & - & .53 \\
\hline Disengagement & - & - & \\
\hline
\end{tabular}

Note $=* \mathrm{p}<0.05, * * \mathrm{p}<.001$

The Result indicated that the perceived Psychological Stress was not significantly correlated with the subscale of Burn out Exhaustion $(r=.07, p<.001)$ and there was no correlation $(r=.53, p<.001)$ of Burn out Disengagement with Perceived Psychological stressamong police constables.

Table-3.4 Correlation Matrix of Age, Perceived Psychological Stress \& Burn out (exhaustion \& disengagement) in Police Constables ( $\mathrm{N}=\mathbf{2 5 0})$

\begin{tabular}{|c|c|c|c|c|}
\hline Variables & $\mathbf{1}$ & $\mathbf{2}$ & $\mathbf{3}$ & $\mathbf{4}$ \\
\hline Age & - & -.17 & -.02 & -.02 \\
\hline PPSS & - & - & .07 & .07 \\
\hline Exhaustion & - & - & - & $.533^{* *}$ \\
\hline Disengagement & - & - & - & - \\
\hline
\end{tabular}

Note $=* \mathrm{p}<0.05, * * \mathrm{p}<.001$

DOI Number: 10.30780/IJTRS.V3.I10.2018.006

pg. 308

WWw.ijtrs.com

wWw.ijtrs.org

Paper Id: IJTRS-V3-I10-006

Volume 3 Issue X, November 2018

@ 2017, IJTRS All Right Reserved 


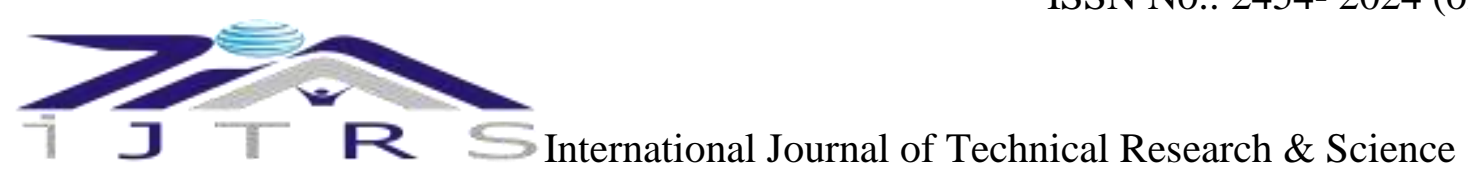

Table 3.4 indicated that age was not significantly correlated with perceived psychological stress $(\mathrm{r}=-.15, \mathrm{p}<$ $0.05)$ and negatively correlated with burn out Disengagement $(\mathrm{r}=-.02, \mathrm{p}<0.05)$. It is also indicated that there is correlation between Psychological stress and the burn out exhaustion $(r=.07, p<0.05)$ respectively.

Table-3.5 One Way Analysis of Variance of Perceived Psychological Stress, Burn Out (Exhaustion \& Disengagement) by Five Cities ( $\mathrm{N}=250)$

\begin{tabular}{|l|l|l|l|l|l|l|l|l|l|l|l|}
\hline & \multicolumn{2}{l}{ Sheikhupura } & \multicolumn{2}{l|}{ Lahore } & \multicolumn{2}{|l|}{ Narowal } & \multicolumn{2}{l|}{ Kasur } & \multicolumn{2}{l|}{ Farooqabad } & \\
\hline Variables & M & SD & M & SD & M & SD & M & SD & M & SD & P \\
\hline PSS & 26.1 & 5.8 & 27.6 & 5.7 & 22.2 & 5.0 & 25.3 & 6.0 & 27.8 & 5.1 & .000 \\
\hline Exhaustion & 22.8 & 3.08 & 11.8 & 3.4 & 18.7 & 4.1 & 18.7 & 6.1 & 18.5 & 6.6 & .000 \\
\hline Disengagement & 26.7 & 6.0 & 20.3 & 4.9 & 18.3 & 2.5 & 20.8 & 3.3 & 21.8 & 2.8 & .000 \\
\hline
\end{tabular}

The results indicated that there is a significant difference in perceived psychological stress (PSS), Burn out (exhaustion \& disengagement) in police constables living in different cities, i.e. Sheikhupura, Kasur, Narowal , Lahore and farooqabad. Further, post Hoc analysis indicated that perceived psychological stress is significantly higher among the police constables of the five cities. It is also indicated that the Burn out statistically significant affect all the police constables of five cities but there is the Mean difference of the Burn out tendency in Sheikhupura city, which emphasized that the police constables living in Sheikhupura having more tendency of burn out as compared to other cities.

\section{DISCUSSION}

The results of the present study concluded that there is a positive correlation between income and perceived psychological stress. Violanti, (1983), conducted a research in UK, examined the experience of perceived psychological stress enhanced in the police constables because of occupational stress. Miller and Smith (2007) designed a model in which demonstrated that the income is correlated with the distress level of the police department.According to the Golembiewski (1988) model, burn out develops in the individual after following the same job or routine for many time, and the job demands and pressure exceeds from a certain level. It was also concluded in the Miller (2007) study that age is not determined with the burn out in the police constables. The results concluded that age was not significantly correlated with the perceived psychological stress and burn out. Nicolien et al., (2010) conducted a research in which investigate that age is not correlated with the police constables but the years of the duty was highly associated with the perceived psychological stress and burn out.Miller (2007) elaborate in his model that the burn out enhance with the same duty and daily routine patterns. It was also indicated that the motivation of the duty was reduced with the passage of the time after performing the same duty and level of stress enhance after occupational demands.

\section{CONCLUSION}

The main contribution of the present research was to explore and investigate whether there is a relationship between perceived psychological stress and burn out. The results indicated that there is a significant correlation between income, burn out and psychological distress. The major contribution of the results is that although the police constables performed the same duty and having the same responsibilities but the level of burn out, perceived psychological stress and acting out tendencies differ in five cities according to their occupational stress and demand of their jobs.

\section{LIMITATIONS}

$>$ The sample was restricted to five cities of one province only. The data may be collected from the entire country to enable generalization.

$>$ The sample was limited, reducing the chances for generalization of the study.

$>$ Qualitative analysis should be incorporated because of the subjectivity of the many factors involved.

\section{ACKNOWLEDGMENT}

I want to acknowledge to Mr. Raheel Ahmed, he helped me in data collection and motivate me at every step while conducting this research. I am also very thankful to my university and parents.

\section{REFERENCES}

[1] Aardema, A. J., Luteijn, F., \&Sanderman, R. (1997). Appraisal of responsibility: A new Questionnaire and its relation to depression, rigid thoughts, and norms. European Journal Of Psychological Assessment. 13(216-218).

[2] Adlam, K. R. (1982). The police Personality: Psychological Consequences of being a police officer. Journal of Police Science and Administration.344-349.

[3] Alkus, S., Padesky, C. (1983). Special problems of police officers: Stress-related issues and interventions 
1 J $\mathrm{R} \leqq$ International Journal of Technical Research \& Science

The Counseling Psychologist. 11(2), 55-64.

[4] Allen, S. W. (1986). Suicide and indirect self-destruction behavior among police. In J. T. Reese \&aH. A.Goldstein (Eds.), Psychological services for law enforcement (pp. 413-417). Washington, DC: U.S. Government Printing Office.

[5] Anderson, E. M. (1995). Stress and its correlates: An empirical investigation among North Dakota peace officers. Unpublished doctoral dissertation, The University of North Dakota.

[6] Anderson, L. M. (1996). Employee cynicism: An examination using a contract violation Framework. Human Relations.

[7] Anson, R. H., \& Bloom, E. (1988). Police stress in an occupational context. Journal of Police Science and Administration. 16141. 229-235.

[8] Bartol, C. R. (1982). Psychological characteristics of small-town police officers. Journal of Police Science and Administration. 10 (1).58-63.

[9] Beehr, T. A., Johnson, L. B., \&Nieva, R (1995). Occupational stress: Coping of police and Their spouses. Journal of Organizational Behavior. 16(1), 3-25.

[10] Beermann, B., \&Nachreiner, F. (1995).Working shifts - different effects for women and men. Work and Stress, 9(2-3), 289-297.

[11]Biggam, F. H., Power, K. G., \& MacDonald, R. R. (1997). Coping with the occupational Stressors of police work: A study of Scottish officers. Stress Medicine. 13. (109-115). 